\title{
Local Government Autonomy In Nigeria: Struggles And Challenges
}

\author{
Ahmed Wali Doho \\ Department of Political Science, Federal University, Kashere \\ Abdulkadir Ahmed \\ Department of Political Science Federal University Kashere. \\ Ado Umar \\ Department of Political Science Federal University Kashere
}

\begin{abstract}
The history and development of local government system in Nigeria passed through two major administrative phases; the pre-colonial and colonial era which influenced de-concentration and the post-independence and 1976 era which was characterized by devolution of authority. Reforms were introduced but were characterized with some challenges. The study, therefore examined the trends, patterns and development of local government system in Nigeria. The researchers primarily made used of secondary source of information. At the end it was discovered that the tier is faced with constitutional problems, and it was recommended for review of 1999 constitution.
\end{abstract}

Keywords: Local government, devolution, autonomy, reforms and development.

\section{INTRODUCTION}

Local governments in Nigeria are single tier government responsible for providing basic services to the people. Local governments exist to provide peculiar services particularly to rural communities. Countries world over, irrespective of system of government, sees local government as essential instrument of national or state government for the performance of certain basic services which could best be administered locally as the intimate knowledge of the needs, conditions and peculiarities of the areas concerned rest with the tier. It also unites people in a defined area in a common organization whose functions are essentially complementary to those of the central government and in the interest of the local residents for the satisfaction of common community needs. As government, it is the means by which the common problems and needs of a community are economically and effectively catered for. This shows that local government is the major source by which a local community satisfies their common needs and problems. However, over time, the performances of these local governments in Nigeria were characterized by some challenges. These include funding, autonomy, infrastructural decay, political instability, constitutional problems etc.

The principle of autonomy is an important issue for local governments because it cannot functions efficiently without appreciable elements of autonomy. History has shown that local government administration prior to 1976 showed the existence of these institutions as mere field units. There was so much dictation by the state government which undermines good initiatives for development at the level. This development informed the 1976 reforms, and with the guarantee of third tier status in the constitution, are expected that these would serve as good breather to local governments. Although evidence has shown that as far back as the 
Second Republic, there was hardly any attempt to democratize the local government due to unnecessary political interference by the state governments.

The paper therefore attempt to assess and examine the historical context of local government in Nigeria, the struggle for local government autonomy, the challenges facing them.

\section{THE CONCEPT OF LOCAL GOVERNMENT}

The precise definition or meaning of concepts has varied across many scholars particularly in social sciences. It was against this backdrop that it attracted the intellectual concerns of many renowned and internationally acclaimed scholars who have analyzed and defined it. Ola (1984) in his contribution defined local government as a political sub-division of a nation, which is constituted by law and has substantial control of local affairs including the powers to impose taxes or to exact labor for prescribed purpose.

According to Blair (1977), local government is rather a resident population occupying a defined area that has a locally authorized and governing body; a separate legal entity, the power to provide certain public or governmental services, and a substantial degree of autonomy adding legal or actual power to raise part of its revenue. The Guidelines for Local Government reform (1976), defined local government as government at the local level established by law to exercise specific powers within defined areas (and) to initiate and direct the provision of services and to determine and implement project so as to complement the activities of the state and federal government in their areas, and to ensure that local initiative and response to local needs and conditions are maximized.

In this case therefore, much emphasis is placed on peculiarity of the tier, and the capacity based on knowledge of the area to initiate and execute services that are much needed by the people in that locality.

\section{HISTORICAL CONTEXT}

The development of local government in Nigeria can effectively be analyzed in five phases viz: colonial native authorities, the rise of modern local government councils in the fifties, the decline of these councils in the sixtieth and the early seventieth, the reforms introduced in 1976 and post 1976 local government administration.

Indeed, the colonial native authorities were established progressively in their rudimentary forms from the 1890 to the 1930s. They represented a system of indirect rule which sought to establish a form of local administration through traditional authorities. In some parts of the country, a problem arose of identifying who these authorities were and re-organization in the 1930s and 1940s led to the establishment of chief-in-council and chiefs and council in the place of sole native authorities, particularly in Southern Nigeria. In due course, selected nontraditional members were introduced in a number of native authorities in the South and this provided training ground for the future leaders at the regional levels (Gboyega, 1987).

In the years 1950-55, the first largely elected local government councils based on the British model emerged in Lagos and the former Eastern and Western Regions. In the former Northern Region, a number of reform measures were introduced in the Native Authority law of 1954 in response to the democratic needs of the people.

The third phase of local government administration was characterized by decline in the prestige and responsibilities of local authorities. This occurred at varying periods in different parts of the country between 1960 and 1966. In the former Western Regions, Government 
(Amendment) Law 1960 abolished the powers of councils to levy education and general rates on the basis of need (Benjamin, 1998). The autonomy was whittled down remarkably. The situation in the former Eastern Region between 1961 and 1967 until the local government councils ceased to exist following the outbreak of the civil war was not better than that described above I respect of the Western Region.

In the former Northern Region up to 1968 there were gradual changes in the structure of councils - with increasing numbers of elected or appointed non-traditional office holders becoming members of local authorities. The result was that the local authorities had a stable administration which enabled them to assume responsibility, with some degree of success, for more complex services like primary education.

It was against this background of depression in the area of local government that the Federal Military Government, in collaboration with the State Governments, embarked in 1976 on extensive local government reforms. This step is significant in one respect in that for the first time in a quarter of a century a national rather than a regional approach was adopted towards local government.

With the implementation of the 1976 reforms, all local governments in the country were allpurpose one-tier local authorities with majority of council members being elected through the secret ballot systems of elections; while the few remaining members were nominated by the state government. Universal adult suffrage was extended to the Northern States for the first time with the enfranchisement of women. While, Okoli (1998) equally described as the first bold attempt at realizing the national objective of unity and integration as envisaged by the federal government, which also hoped by so doing to protect the system from states' stifling controls The aim of the reform was to institute an enduring local government council system; the creation of a system that could serve as a catalyst for the development of the areas involved; a uniform structure through the one tier system; recognizing the position of traditional rulers and a need to guide against the situation where the state governments have continue to encroach upon what would normally have been the exclusive preserves of local governments (NULGE, 2003)

When the 1976 reforms failed to produce the desired goal, the Dasuki Committee was constituted in 1984 which in its reports, it largely amplified the need to strengthen the autonomy of local government system. Its major recommendations are:

1. The scrapping of State Ministries for Local Government and all responsibilities of the ministry was transferred to unit under the Deputy Governors office.

2. Direct disbursement of statutory allocation

3. Creation of additional local governments

4. Review of allocation formula

5. Transfer of Primary Health care program to local governments

6. Transfer of Primary Education to local governments

7. Separation of power at the local government

8. The appointment of political secretaries at the local government

9. The institution of 774 local governments in the constitution

All these good recommendations were implemented, but the predicament of local government autonomy in Nigeria persisted. This therefore, led to setting up of the Etsu Nupe committee in 2003, which led to the recognition of local government as the autonomous third tier of government of Nigeria; the abolition of the state - local government joint account and direct remittance of each local government council of its own share of the federation account. 
The critical phase which vitiated the autonomy of the system and virtually relegated the tier to mere administrative agency of the respective state governments was the time when the military handover to civilian administration in 1999. Adeyemo (2005) rightly summarized the challenges as constitutional provisions, political instability and financial/fiscal problems. Since then, the country is faces with four major issues that undermines local government autonomy, these are:

- The constitution was not clear on the delegation of authority between the states and local governments in areas of concurrent responsibilities.

- Ambiguities in the responsibility for creation of local government areas which remain inchoate and are included in the fourth schedule of the constitution.

- Problems related to the equitable distribution of federal revenues amongst the three tiers of government.

- Clear encroachment and breach of the local government fiscal autonomy which dispose the state.

This development made Odo (2014) to assert that the local governments suffer from constant whittling down of their powers by the state governments. The excessive control of some local governments by the states has reduced them to local administration or local arms of state administration. Although the 1999 constitution attempt to provide some clause in terms of autonomy and fiscal relations, but yet the ambiguous provisions therein further frustrate the local government system in the country.

\section{THE STRUGGLE FOR LOCAL GOVERNMENT AUTONOMY IN NIGERIA}

The period 1951 to 1976 , the then regional and later state governments had absolute control over local governments. They determine the structure, functions and powers devolved to the tier, and autonomy was non-existent. But with the introduction of the 1976 reforms, it brought a major change in intergovernmental relations which were meant to unchain local governments from the excessive control exercised by the state governments. Scholars, including Ammani (2012) commenting on this issue, have described how state governments seize federal allocations meant for local governments in their domain and misappropriate them; leaving the local governments debilitated. This is the kind of interference that caught the attention of scholars and practitioners, and even this piece of article.

The system suffered from continuous whittling down of their powers, inadequate funds and appropriate institutions, inadequate staffing arrangement and the institution was divorced from people and governmental institutions at their most basic levels. The reform devolved functions and power to perform these functions to the local government, but at the same time placed under the control of the state.

The Buhari led military government (1983 - 1984) appointed the Committee to review the system of local government headed by Alhaji Ibrahim Dasuki made a good recommendations as earlier mentioned above. It gave the local government the required autonomy to operate freely with little or no interference, but the report was not fully implemented before the regime was overthrown in 1985.

The General Ibrahim Babangida regime resolved that local governments will no longer be subject to any control by federal and state governments. It was the glorious period for local government system in the country. The regime introduced the Presidential system of government at the local level in 1991 which was in line with the contribution on the literature of autonomy by Davey (1991) where he opined that "Local autonomy is primary concerned with the question of responsibilities, resources and discretion conferred on the local 
authorities. As such discretion and responsibility are at the core of local government". This development resulted in the election of local government chairmen with full executive powers through universal adult suffrage; upward review of sharing formula to local governments from $10 \%$ to $15 \%$ and later $20 \%$; direct release of federal allocation without channeling it through the state; the abolishing of the Ministry for local government and replacing it with department of local government placed under the Deputy Governor's office; the abolishing to local government service commission and appointment of the Secretary to the local government. Inspite of the recorded lapses from the operators of the system, this was the time autonomy was fully granted to local governments in the country.

The final stroke that broke the camel's back was the 1999 constitution which revised the autonomy of the tier. Watt (1996) pointed out that the implications of this arrangement has been some kind of ambivalence in the control of local governments that manifests the underlying centripetal and centrifugal tensions between the federal and state forces in Nigerian federalism. (Opara, 2016:1) is quoted saying "in all federations, finance is the most critical policy issue in intergovernmental relation".

The encroachment of local finance and the level of interference by the other higher government as it relates to revenue sharing have continually remained issues in the front burner of the nation's polity by the state government. This has negatively affected the performance of local government in terms of its constitutional responsibilities. The situation is further deteriorating and getting worst by the day. The only organized body that is championing the cause of local government autonomy in the country is the Nigeria Union of Local Government Employees (NULGE). The union presented a number of position papers to conferences and committees, and now the struggled has reached its peak with nationwide protests staged in support of local government autonomy.

\section{RATIONALE FOR LOCAL GOVERNMENT AUTONOMY}

There are a number of reasons advanced by those advocating for local government autonomy, but the generally agreed reasons are that the autonomy will:

- political education - Local government autonomy will develop the system, and help in educating the people in the rural areas to acquire knowledge of the political system

- strengthen democratic decentralization of power and putting power in the hands of citizens at the grassroots level governance, in addition to delivering development

- deliver development evenly to each and every Nigerian since each person resides in a local council located in either the rural, semi-rural or urban area

- it enables capacity building of people in rural areas which will be in form of economic empowerment through job creation and payment of salary and emoluments or freedom from external control of allocation which the excess can be channeled into the economic system of the communities concern

- Make the working environment functional and less threatening to the survival of the system. Local government employees in most of the states of the federation are not getting their salaries when due, and retirement benefit is no forthcoming even years after retirement from the service. This will give the workers a sense of job security and motivation which will encourage them to put in their best

- Guarantee more money in the hands of local government to deliver services to citizens since it weakens the over-concentration of power in the state. Local contractors can now rely on the tier instead of the state and federal, and this may develop their capacity to handle more bigger and complex project in the future 
- Provide a voice to minorities who will have representation at the local government level. Minorities no matter the size of their population will be part of the political equation and process of making the councilor or chairman of their local government

- Put more powers in the hands of citizens and their institutions and thus help them demand for accountability, transparency and developments. By virtue of citizen's participation in making the government, they decision making process, policy initiation and monitoring.

These and many more reasons are the driving force for stakeholders and activists who are working to ensure citizen's participation in governance at all levels believed in. Countries all over the world are shifting attention to the local government and decentralization of responsibilities.

\section{FACTORS UNDERMINING LOCAL GOVERNMENT AUTONOMY IN NIGERIA}

There are numerous challenges facing local governments in Nigeria, these ranges from institutional fragility to systemic decay in the polity. But the following are the most problematic areas that are posing challenges to autonomy of the tier in the country. These include:

- Constitutional issues - The 1999 constitution of the Federal Republic of Nigeria (as amended) made it difficult for local governments in the country to operate as an autonomous tier because of its provisions that relates to that level of government in the federal arrangement. Financially, the constitution provides for a joint state - local government account which all revenues accrued are pooled there, and this gives the state governors an opportunity to deny local governments what is due to them. Furthermore, the existence of the state independent electoral commission dedemocratize the system and pave way for plating stooges of the state governor. The challenge therefore is that the process of amending the constitution is difficult and prone to state governor's manipulation.

- Appointment of Caretaker Committees - As a result of the constitutional lapses, caretaker committees are mostly appointed in most of the states instead of elected council members. This undemocratic practice disenfranchises the citizens at the grassroots, and made the leadership subservient to the state governors instead of the electorates. This creates political apathy in the minds of the citizenry, and denying them their civic rights. The governors are using this platform for their political gains, and making it difficult for local autonomy.

- Poor Manpower Planning - The local governments in the country are faced with over populated staff because they have little or no control over staffing as such increasing the wage bill and creating redundancy. The political elites in the state are using this to employ their followers and thugs whom ideally cannot be employed in the state service. The consequences of this are spending all resources on payment of salaries instead of services to communities in the area, and for the governors is an avenue to reduce the pressure on them.

- State - Local government joint projects - State Governors use their powers and compelled local governments to engage in joint projects which has little or no relevance to the people of the areas instead of allowing the tier to come up with projects that were initiated by the people who felt that it is an area that they needed the local governments to address. In most cases, these projects are either abandon or left without commissioning resulting into a waste of resources or channeling a huge sum that may be used to execute a number of projects in the area. Although such joint-projects are being done with the consent of the councils, but in most cases, they lacked the powers to reject the idea because they were not elected in free and fair elections as such they are 
only obeying the directives of their political godfathers at the expense of the majority populace. The ultimate result is that people at the grassroots are not carried along and they lost confidence in what the local governments can do.

- Corruption - The excessive control by the states result in widespread corruption coordinated at the state level through its overseeing organs such as the Ministry for Local Government and the Joint Account meetings. Money meant for the development of rural areas are being siphoned and shared or used for political activities of the ruling party controlling the state. And in some cases, the money is diverted to another council to upset deficit at the detriment of the real owners. But if the local governments can have their allocations directly, it will be easier to hold the council accountable for their actions.

- Poor delivery of service - Because of misplaced priority as a result of fear and obedience to the political elites at the state level, basic essential services such as Primary Health Care and Primary Education which constitutes some of the basic constitutional functions of the local governments are neglected. Instead, huge sums of money are diverted for running State Universities and Tertiary institutions creating a major setback in these essential areas.

These and many more reasons informed the using of the state houses of assemblies by governors in the federation and coupled with the constitutional lapses to block all efforts that may lead to local government autonomy in the country.

Conclusively therefore, the 1999 constitution of the Federal Republic of Nigeria created fundamental contradictions, conclusions and ambiguity that have been exploited to decimate the local government and subsequently made them appendages tied to the State Governments, so much so that in some states they are mere extensions of the State Ministry for Local Governments.

The local government autonomy in the country is a euphemism particularly with the provisions of section 8 (subsection $5 \& 6$ ), section 5 , and the return of state - local government joint account as adopted from the 1976 constitution. This has become one of the greatest tragedies that have befallen the Local Government system in the country.

\section{RECOMMENDATIONS}

The study therefore recommended the following suggested constitutional amendments if local governments in the country are to be autonomous and to function to the satisfaction of the citizens:

- Section 7 (1) of the constitution and all the phrasing appearing after the words 'and accordingly' should be deleted

- Insist on full observance of the provisions on democratically elected local councils to avoid appointment of caretaker committees

- There should be provision that vested Executive powers to the chairmen and councilors on matters that are local in nature

- Structure, finance, establishment, composition and functions of local government councils should not be vested in state house of assembly but the constitution

- There is a need to expunge the State Independent Electoral Commission from the constitution, and replaced with Local government Service Commission and Local Government Audits

- The constitution need to spelt out the functions of the Chairman and Councilors to make each relevant in the arrangement 
- The tenure of the councils needs to be stated, preferably four years so that elections can be held simultaneously with the state.

\section{Reference}

Adeyemo, D.O. (2005). "Local Government Autonomy in Nigeria: A Historical Perspective”, Journal of Social Science, 10(2): 77-87

Ammani, A. (2012): "Local government in the Nigerian Federation”, culled from www.gamji.com/article

Benjamin, S. A. (1998). Local Government Autonomy in Nigeria: its Implications for the Federal Structure. Ibadan, Nigerian Institute of Social Research and Economic Research (NISER).

Blair, G. S. (1977). Government at the Grassroots. California, Palisades Publishers.

Davey, K.J. 1991. Local Autonomy and Independent Revenue. Journal of Public Administration, 49: 45.

Gboyega, A. (1987). Political Values and Local Government in Nigeria. Lagos, Malthouse Press Ltd.

The 1976 Guidelines for Local Government Reform, Federal Government of Nigeria. Lagos, Government publishers.

Nigeria Union of Local Government Employees (2003). A Position Paper Presented at CONFAB, Abuja (Unpublished).

Odo, L.U (2014). "Local Government and the Challenges of Grassroots Development in Nigeria”, Review of Public Administration and

Management Vol. 3, No. 6, Pp204-213

Okoli, F.C. (1998) An Introduction to the Theory and Practice of Local Government: A Nigerian Perspective, Nsukka: Topmost Printing Press

Ola, R. F. (1984). Local Administration in Nigeria. London, Kegan Paul International.

Opara, S. C. (2016) “Local Government Service Commission and Challenges of Local Government Autonomy in Nigeria: An Evaluation, Public Policy and Administration Research, Vol.6. No.5

Watts, R. (1996). Comparing Federal Systems in the 1990s. Kingston, Ontario: Queen's University Institute of Intergovernmental Relations 